\title{
INFLUENCE OF DIETARY VITAMIN C SUPPLEMENTATION ON GROWTH PERFORMANCE, BLOOD BIOCHEMICAL PARAMETERS AND TRANSCRIPT LEVELS OF HEAT SHOCK PROTEINS IN HIGH STOCKING DENSITY REARED BROILER CHICKENS
}

\author{
Ramadan S. Shewita ${ }^{1}$, Karima El-Naggar ${ }^{1}$, Walaa S. H. Abd El Naby²*
}

${ }^{1}$ Department of Nutrition and Veterinary Clinical Nutrition, Faculty of Veterinary Medicine, Alexandria University, Egypt, ${ }^{2}$ Genetics and Genetic Engineering, Department of Animal Husbandry and Animal Wealth Development, Faculty of Veterinary Medicine, Alexandria University, Egypt

${ }^{*}$ Corresponding author, E-mail: walaa.slouma@yahoo.com

\begin{abstract}
This study was conducted to evaluate the effects of dietary supplementation of different levels of vitamin $\mathrm{C}(\mathrm{VC})$ in broiler chicken reared under high stocking density on the growth performance, blood biochemical parameters and the expression of heat shock protein genes. A total of 150, one day old mixed sex broiler chicks (Cobb 500) were randomly distributed in five equal groups. Group1 was reared in normal stocking density (10.6 birds $/ \mathrm{m}^{2}$ ) and fed on the basal diet (BD) without VC (control). While, chicks in other groups $(2,3,4$ and 5$)$ reared in high stocking density $\left(15.6\right.$ birds $\left./ \mathrm{m}^{2}\right)$ and fed on $\mathrm{BD}$ supplemented with VC at 0,200, 400 and $600 \mathrm{mg} / \mathrm{kg}$ diet, respectively. Birds reared in high stocking density showed a reduction of the final body weight and total feed intake, with high mortality (6.6\%). Moreover, they revealed a significant up-regulation of HSP70 mRNA and elevated HSP9O and HSF1 mRNA expression in heart and liver tissue. Graded dietary levels of VC provided variable protection against the hazard of high density through improved final body weight and total feed intake, decreased the mortality \% and downregulated liver HSP70 expression level. However, the best performance was observed in birds supplemented with $200 \mathrm{mg} / \mathrm{kg}$ VC (group 3).
\end{abstract}

Key words: chicks' growth performance; gene expression; stocking density; vitamin C

\section{Introduction}

Broiler production facing many forms of stressor including high ambient temperature, nutritional stress (imbalance or deficiency in the nutrient requirements) and vaccination programs stress as well as diseases. It is known that birds will perform better when grown in more space, hence, high stocking density (SD) is considered one of these stressful factors which have undesirable effects on broiler performance, livability, health and immune system response, as it reduces bird access to feed and water (1). It also leads to raising the environmental temperature dangerously where more metabolic heat will be added to the house air than was planned (2).

Different feed additives have a role in reducing stress in broiler feed are included in several studies (3-5). The ameliorative effects of ascorbic acid or vitamin C (VC) in many forms of 
stressors have been documented $(6,7)$. The heat shock proteins (HSPS) family is highly homologous chaperone proteins contributing to cellular protection, protein homeostasis and cell survival against a variety of environmental and metabolic stresses. HSP70 is one of the most conserved and important protein which plays a deep role in enhancing tolerance to various stressors in broiler chickens $(8,9)$. Different studies indicated that $\mathrm{HSP} 70$ has an importance not only at high ambient temperatures but also in cell death mediated by free radicals and reactive oxygen species (10). Furthermore, in both physiological and stress conditions $H S P 90$ is a molecular chaperone involved in maturation and stabilization of a wide range of proteins to maintains cellular homeostasis and function (11). We hypothesized that VC could modulate the negative impacts of high stocking density as a stress factor in broilers farms

Therefore, this study aimed to investigate the effect of dietary VC supplementation with different concentrations on growth performance, some blood biochemical parameters, and heat shock protein genes expression in broiler chicks reared under high stocking density.

\section{Material and methods}

This experiment was approved by the local ethical committee of animal use from Faculty of Veterinary Medicine, Alexandria University.

\section{Birds, experimental design and feeding Program}

One hundred and fifty, one-day-old mixed sex Cobb 500 broiler chicks were used in this study. The chicks were weighed at one day old and then randomly distributed into five groups (30 chicks/ group), each treatment has three replicates (10 chicks/replicate) in 15 compartments, every compartment was provided by a suitable feeder and waterer. All groups received their experimental diet for 6 weeks. The bird's compartments were bedded with fresh, clean chopped wheat straw forming a deep litter of 4 $\mathrm{cm}$ depth. The room temperature was adjusted on $33^{\circ} \mathrm{C}$ in the first week of age after that decreased $3{ }^{\circ} \mathrm{C} /$ week until reaching $21^{\circ} \mathrm{C}$ at the fifth week of age and the relative humidity was kept at $70 \%$. The chicks were vaccinated according to a normal regime (vaccination against Newcastle disease on days 7, 18 and 28 and infectious bursal disease (Gumboro) on day 12 of chicks age).

The broiler chicks were fed on the basal diet (BD) prepared from a corn-soybean meal based diet and were formulated to meet the nutrient requirements of poultry (12). Starter diet was given from 0-2 weeks of age, followed by grower diet (3-4 weeks) and finally finisher diet from 5-6 weeks of age. Chicks of group 1 (G1), were fed on BD without VC supplementation and reared in normal stocking density (10.6 birds $/ \mathrm{m}^{2}$ ), while the chicks of groups G2, G3, G4 and G5 distributed to be in high stocking density (15.6 birds $/ \mathrm{m}^{2}$ ) (13) and fed on the BD supplemented with VC (Introvit-C WS, Interchemie Co., Netherland) at levels of 0, 200, 400 and $600 \mathrm{mg} / \mathrm{kg}$ diet, respectively. The composition of experimental diet and its calculated analysis were presented in table (1). Data for final body weight (BWT) and feed intake (FI) were recorded. Feed conversion ratio (FCR) and body weight gain (BWG) were calculated.

\section{Sample collection}

At the end of the experiment, three blood samples from each replicate $(n=9)$ were collected for analysis of some biochemical parameters, separation of the serum was done using centrifuge adjusted at $3000 \mathrm{rpm}$ for 10 minutes then stored in $-20^{\circ} \mathrm{C}$. The serum was used for measuring serum total cholesterol, high density lipoprotein (HDL), low density lipoprotein (LDL), triglycerides, glucose, total protein, albumin, globulin, serum glutamic pyruvic transaminase (SGPT) and serum glutamic oxaloacetic amino-transferase (SGOT) using commercial kits (Biodiagnostic company, Egypt). The analysis was done by using a spectrophotometer according to the manufacture instructions. The liver and heart tissues from the same slaughter birds were collected and homogenized then snap frozen in liquid nitrogen immediately and stored at $-80^{\circ} \mathrm{C}$. 
Table 1: Composition of experimental starter, grower and finisher diets ( $\mathrm{gm} / \mathrm{kg}$ diet) and calculated chemical analysis of the basal diet

\begin{tabular}{|c|c|c|c|}
\hline \multirow{2}{*}{ Ingredients } & \multicolumn{3}{|l|}{ Diet } \\
\hline & Starter & Grower & Finisher \\
\hline Yellow corn & 542 & 558.8 & 606 \\
\hline Soybean meal (44\%) & 319 & 281 & 253.3 \\
\hline Corn gluten meal (60\%) & 71 & 81 & 48.1 \\
\hline Vegetable oil & 29.8 & 41 & 54.4 \\
\hline Limestone $^{1}$ & 15 & 15 & 15 \\
\hline Monocalcium phosphate & 14 & 14 & 14 \\
\hline Common salt & 3 & 3 & 3 \\
\hline Mineral Premix $^{2}$ & 1.5 & 1.5 & 1.5 \\
\hline Vitamin Premix ${ }^{2}$ & 1.5 & 1.5 & 1.5 \\
\hline Methionine $^{3}$ & 1 & 1 & 1 \\
\hline Lysine $^{4}$ & 1 & 1 & 1 \\
\hline Anti Coccidial $^{5}$ & 0.2 & 0.2 & 0.2 \\
\hline Antimold $^{6}$ & 1 & 1 & 1 \\
\hline \multicolumn{4}{|l|}{ Calculated Analysis } \\
\hline Crude protein $(\mathrm{CP}) \%$ & 23.1 & 22.18 & 19.39 \\
\hline $\begin{array}{l}\text { Metaboliziable } \\
\text { Energy (ME) Kcal / kg di }\end{array}$ & 3053 & 3160.7 & 3252.6 \\
\hline Calorie / protein ratio ${ }^{8}$ & 132.16 & 142.5 & 167.7 \\
\hline
\end{tabular}

${ }^{1}$ Limestone (contain 36\% calcium). Monocalcium phosphate: contain $22 \%$ Phosphorus and $16 \%$ Calcium. ${ }^{2}$ Mineral and Vitamin premix produced by Heropharm and composed (per $3 \mathrm{~kg}$ ) of vitamin A $12000000 \mathrm{IU}$, vitamin D32500000 IU, vitamin E $10000 \mathrm{mg}$, vitamin K3 $2000 \mathrm{mg}$, vitamin B1 $1000 \mathrm{mg}$, vitamin B2 $5000 \mathrm{mg}$, vitamin B6 $1500 \mathrm{mg}$, vitamin B1210 mg, niacin 30000mg, biotin $50 \mathrm{mg}$, folic acid $1000 \mathrm{mg}$, pantothenic acid $10000 \mathrm{mg}$, manganese 60000 $\mathrm{mg}$, zinc $50000 \mathrm{mg}$, iron30000 mg, copper $4000 \mathrm{mg}$, iodine $300 \mathrm{mg}$, selenium $100 \mathrm{mg}$ and cobalt $100 \mathrm{mg} .{ }^{3} \mathrm{DL}-$ Methionine (Produced by Evonic Co and contain $99 \%$ methionine), ${ }^{4}$ Lysine = lysine hydrochloride (contain $98 \%$ Lysine). ${ }^{5}$ Kill cox, Produced by Arabian company for pharmaceutical industries, 6 Produced by EL TOBA CO. For Premixes \& Feed El-Sadat city Egypt. ${ }^{7}$ ME calculated according to NRC $(1994),{ }^{8}$ Calorie /protein ratio $=$ ME Kcal $/ \mathrm{CP} \%$

Table 2: Primers used for quantitative real-time PCR

\begin{tabular}{lll}
\hline Gene and ID & Primer Sequence (5`-3`) & References \\
\hline HSP70 & F: CCAAGAACCAAGTGGCAATGAA & $(15)$ \\
$($ EU747335) & R: CATACTTGCGGCCGATGAGA & \\
\hline$H S P 90$ & F: GAGTTTGACTGACCCGAGCA & $(15)$ \\
(NM_206959) & R: TCCCTATGCCGGTATCCACA & \\
\hline$H S F 1$ & F:CAGGGAAGCAGTTGGTTCACTACACG & $(15)$ \\
$($ L06098.1) & R: CCTTGGGTTTGGGTGCTCAGTC & \\
\hline GAPDH & F: GGGCACGCCATCACTATCTTC & $(16)$ \\
(NM_204305) & R: ACCTGCATCTGCCCATTTGA & \\
\hline
\end{tabular}


R. S. Shewita, K. El-Naggar, W. S. H. Abd El Naby

Table 3: Effect of different dietary VC supplementation on growth performance of broiler chickens

\begin{tabular}{llllll}
\hline Parameters & G1 & G2 & G3 & G4 & G5 \\
\hline $\begin{array}{l}\text { W0 } \\
\text { (Initial wt.) }\end{array}$ & $45.64 \pm 0.48$ & $45.64 \pm 0.54$ & $45.63 \pm 0.52$ & $45.61 \pm 0.56$ & $45.69 \pm 0.46$ \\
\hline $\begin{array}{l}\text { W6 } \\
\text { (Final wt.) }\end{array}$ & $2549.82 \pm 72.73$ & $2470.45 \pm 80.91$ & $2643.50 \pm 73.00$ & $2575.18 \pm 64.14$ & $2540.00 \pm 55.58$ \\
\hline TBG (g) & $2504.18 \pm 72.27$ & $2424.82 \pm 80.39$ & $2597.87 \pm 72.50$ & $2529.57 \pm 63.60$ & $2494.31 \pm 55.14$ \\
\hline TBG, RTG2 & 103.27 & 100 & 107.14 & 104.32 & 102.87 \\
\hline TFI (g) & 4747.17 & 4494.32 & 4590.43 & 4604.81 & 4507.83 \\
\hline TFI, RTG2 & 105.63 & 100 & 102.14 & 102.46 & 100.30 \\
\hline FCR & 1.90 & 1.85 & 1.77 & 1.82 & 1.81 \\
\hline FCR, RTG & 102.70 & 100 & 95.68 & 98.38 & 97.84 \\
\hline Mortality $\%$ & 3.3 & 6.6 & 3.3 & 0 & 0 \\
\hline
\end{tabular}

$\mathrm{TBG}=$ Total body gain, $\mathrm{TFI}=$ Total Feed intake, $\mathrm{FCR}=$ Feed conversion ratio (Feed intake/ body gain), RTG2= Relative to group 2

Table 4: Effect dietary VC supplementation on some blood biochemical parameters of broiler chickens

\begin{tabular}{llllll}
\hline Parameters & $\mathrm{G} 1$ & $\mathrm{G} 2$ & $\mathrm{G} 3$ & $\mathrm{G} 4$ & $\mathrm{G} 5$ \\
\hline $\begin{array}{l}\text { Total protein } \\
\text { (g/dL) }\end{array}$ & $6.12 \pm 0.02$ & $6.14 \pm 0.14$ & $6.04 \pm 0.10$ & $6.14 \pm 0.08$ & $6.12 \pm 0.14$ \\
\hline $\begin{array}{l}\text { Albumin } \\
\text { (g/dL) }\end{array}$ & $5.23 \pm 0.08$ & $5.27 \pm 0.02$ & $5.23 \pm 0.05$ & $5.24 \pm 0.02$ & $5.27 \pm 0.02$ \\
\hline $\begin{array}{l}\text { Globulin } \\
\text { (g/dL) }\end{array}$ & $0.89 \pm 0.10$ & $0.87 \pm 0.13$ & $0.81 \pm 0.13$ & $0.90 \pm 0.10$ & $0.85 \pm 0.13$ \\
\hline $\begin{array}{l}\text { Cholesterol } \\
(\mathrm{mg} / \mathrm{dL})\end{array}$ & $200.6 \pm 5.01$ & $198.27 \pm 2.33$ & $189.37 \pm 6.08$ & $191.00 \pm 1.60$ & $190.83 \pm 5.40$ \\
\hline $\begin{array}{l}\text { Triglyceride } \\
(\mathrm{mg} / \mathrm{Dl})\end{array}$ & $200.43 \pm 2.42^{\mathrm{a}}$ & $200.70 \pm 0.64^{\mathrm{a}}$ & $199.73 \pm 0.65^{\mathrm{a}}$ & $201.07 \pm 1.85^{\mathrm{a}}$ & $184.53 \pm 8.48^{\mathrm{b}}$ \\
\hline $\begin{array}{l}\text { HDL } \\
(\mathrm{mg} / \mathrm{dL})\end{array}$ & $54.50 \pm 0.99^{\mathrm{a}}$ & $55.93 \pm 0.18^{\mathrm{a}}$ & $51.80 \pm 1.10^{\mathrm{ab}}$ & $52.87 \pm 0.94^{\mathrm{b}}$ & $50.80 \pm 1.38^{\mathrm{b}}$ \\
\hline $\begin{array}{l}\text { LDL } \\
(\mathrm{mg} / \mathrm{dL})\end{array}$ & $106.01 \pm 6.44$ & $107.19 \pm 2.30$ & $97.62 \pm 5.67$ & $106.92 \pm 2.24$ & $103.13 \pm 5.76$ \\
\hline $\begin{array}{l}\text { Glucose } \\
(\mathrm{mg} / \mathrm{dL})\end{array}$ & $204.07 \pm 0.94^{\mathrm{b}}$ & $212.97 \pm 1.09^{\mathrm{a}}$ & $209.70 \pm 1.66^{\mathrm{ab}}$ & $206.93 \pm 3.90^{\mathrm{ab}}$ & $206.53 \pm 2.07^{\mathrm{ab}}$ \\
\hline $\begin{array}{l}\text { SGOT } \\
(\mathrm{U} / 100 \mathrm{~mL})\end{array}$ & $39.67 \pm 4.67 \mathrm{a}^{\mathrm{b}}$ & $43.67 \pm 1.76^{\mathrm{a}}$ & $39.33 \pm 4.67^{\mathrm{ab}}$ & $39.67 \pm 4.63^{\mathrm{ab}}$ & $32.33 \pm 1.33^{\mathrm{b}}$ \\
\hline $\begin{array}{l}\text { SGPT(U/100 } \\
\text { mL) }\end{array}$ & $88.33 \pm 2.03$ & $90.33 \pm \pm 3.18$ & 88.671 .20 & $88.33 \pm 2.33$ & $88.33 \pm 2.96$ \\
\hline
\end{tabular}

Means with different letters in the same row differ significantly $(P<0.05)$.

$\mathrm{HDL}=$ High density lipoprotein, $\mathrm{LDL}=$ Low density lipoprotein, SGOT= Serum glutamic pyruvic transaminase and SGPT = Serum glutamic oxaloacetic amino-transferase 


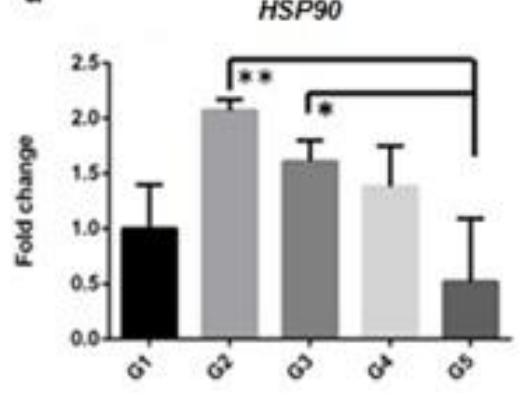

b

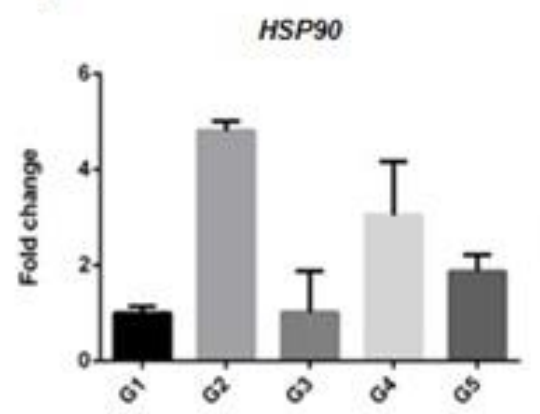

HSP70

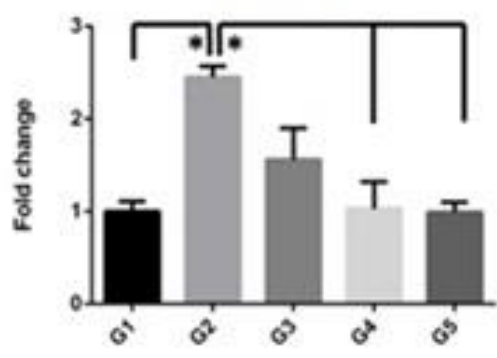

HSP70

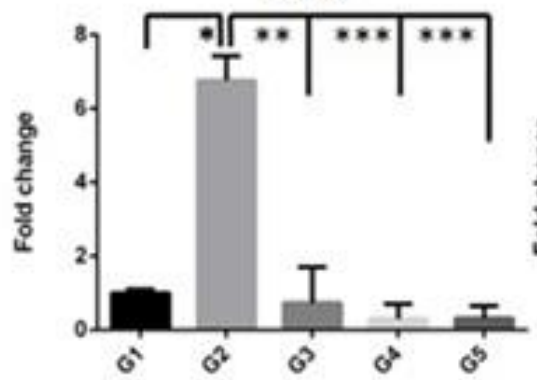

HSF1

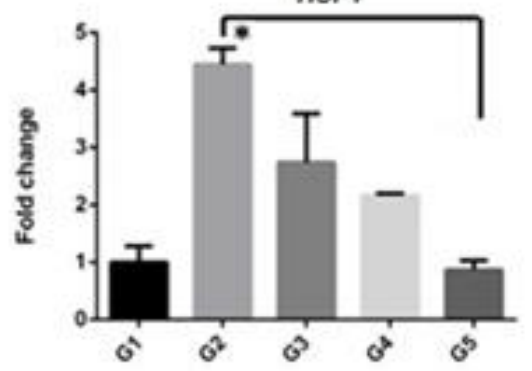

HSF 1

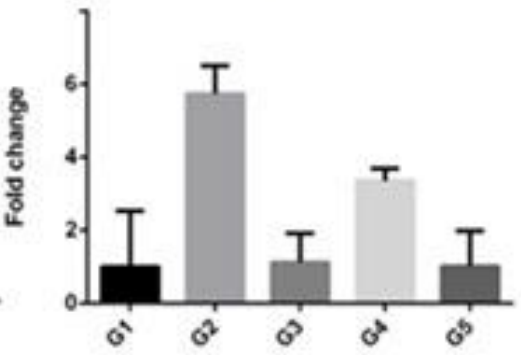

Figure 1: The mRNA expression level of heat shock proteins (HSP90, HSP70 and HSF1) genes in heart tissue (a) and liver (b). Asterisks on the data bars indicated when $\mathrm{P}<0.05(*), \mathrm{P}<0.005(* *)$, and $\mathrm{P}<0.0005$ (***). G1 (chicks were reared in normal stocking density and fed on the basal diet), G2 (chicks were reared in high stocking density and fed on the basal diet), G3, G4, and G5 (chicks were reared in high stocking density and fed on the basal diet with VC supplementation $(200,400,600 \mathrm{mg} / \mathrm{kg}$ diet) respectively

\section{Total RNA isolation and cDNA synthesis}

Total RNA of liver and heart tissues was isolated using the Biozol (Bioflux, Japan) according to the manufacturer instructions. The cDNA was synthesis from isolated RNA using the SensiFAST ${ }^{\text {TM}}$ CDNA Synthesis Kit (Bioline, United Kingdom) according to the manufacturer instructions. Briefly, $4 \mu \mathrm{l}$ of total RNA mixed with $4 \mu \mathrm{l} 5 \mathrm{X}$ buffer, $1 \mu \mathrm{l}$ reverse transcriptase and $11 \mu \mathrm{l}$ RNasel DNase free $\mathrm{H} 2 \mathrm{O}$ was added. The reaction was incubated at $25^{\circ} \mathrm{C}$ for $10 \mathrm{~min}, 42^{\circ} \mathrm{C}$ for $15 \mathrm{~min}$ (reverse transcription) and $4^{\circ} \mathrm{C}$ hold. The obtained synthesis cDNA was checked by glyceraldehyde 3-phosphate dehydrogenase (GAPDH) gene and stored at $-20^{\circ} \mathrm{C}$ until further use.

\section{Quantitative real-time PCR and data analysis}

Quantitative Real-Time PCR (qRT-PCR) was performed for detecting the expression levels of HSP70, HSP90 and HSF 1 genes in heart and liver tissues using specific primers for each gene (Table 2) and SensiFAST ${ }^{\text {TMSyber green }}$ master mix with low Rox (Bioline, United Kingdom) in the Mx3000P ${ }^{\circledR}$ System (Stratagene, USA). The amplification reaction was 20 $\mu 1$ consisting of $2 \mu \mathrm{l}$ cDNA, $0.8 \mu 1$ primers (50 $\mathrm{nm}), 10 \mu 1$ Syber green master mix and up to 20 $\mu 1$ RNase $\backslash$ DNase free H2O. The PCR thermal program started as $95^{\circ} \mathrm{C}$ for $10 \mathrm{~min}$ followed by 40 cycles of $95^{\circ} \mathrm{C}$ for $15 \mathrm{sec}$ then $60^{\circ} \mathrm{C}$ for 60 sec. The dissociation curve was carried at the end of the last cycle. The housekeeping gene $(G A P D H)$ used to normalize threshold cycle value $(\mathrm{Ct})$. The relative expression values were determined using comparative threshold cycle method $2^{-\Delta \Delta \mathrm{CT}}(14)$ and the results were reported as fold change differences relative to the control group (G1).

\section{Statistical analysis}

The obtained data were analyzed using the statistical analysis system (17). The significance designated at $\mathrm{P}<0.05$ for the differences 
among the different experimental groups for all studied parameters. The significance designated as $(\mathrm{P}<0.05)$ using one-way ANOVA between all genes in studied groups.

\section{Results}

Final BWT was improved in all groups which reared under high SD and fed diet supplemented with different levels of VC compared to $\mathrm{G} 2$ (Table 3 ). The $\mathrm{G} 3$ which received VC (200 mg/kg diet) showed the highest final BWT compared to $\mathrm{G} 2$. The $\mathrm{G} 5$, which received the highest level of $\mathrm{VC}(600 \mathrm{mg} / \mathrm{kg})$ showed lower final BWT. The total body gain (TBG) of birds was improved in all studied groups supplemented with VC when compared with G2 with the highest TBG of chicks was found in G3 which subjected to high SD and supplemented with VC at $200 \mathrm{mg} / \mathrm{kg}$ diet. The lowest TBG was found in G2 that was in high SD without VC supplementation. Additionally, High SD in G2 decreased total feed intake (TFI) compared to G1. While the addition of VC in G3, G4, and G5 increased the TFI when compared with G2. The overall chick mortality percentage during the experiment was the highest in G2 $(6.6 \%)$, but it was decreased in G3 (3.3\%) with 200 $\mathrm{mg} / \mathrm{kg}$ diet VC supplementation. Also, no mortality was observed with increased VC supplementation in G4 and G5 (400 and $600 \mathrm{mg} / \mathrm{kg}$ diet) (Table 3).

The addition of VC in G3, G4 and G5 alleviated the stress effect induced by high $\mathrm{SD}$ through decreasing the level of serum glucose, cholesterol, SGOT and SGPT compared with those reared in high SD without VC supplementation (Table 4).

In the present study, rearing broiler chicken in high SD leads to an alteration in the expression of HSPS (HSP70 and HSP90), and HSF in heart and liver tissue (Figure 1a and $b$ ). The expression level of HSP70 mRNA in both heart and liver tissue revealed a significant up-regulation $(\mathrm{P}<0.05)$ in the $\mathrm{G} 2(2.35 \pm 0.12$ and 6.76 \pm 0.66 fold) relative to the control. While HSP70 mRNA expression in both tissues markedly lowered in chicken reared in high SD and supplemented with different concentration of
VC than G2. The G2 showed an increase in expression level of HSP9O and HSF 1 (2.07 \pm 0.10 and $4.45 \pm 0.28$ ) in the heart tissue than $\mathrm{G} 3, \mathrm{G} 4$, and G5 supplemented with VC (200, 400 and $600 \mathrm{mg} / \mathrm{kg}$ ration, respectively). The $H S P 90$ expression level also showed a significant increase $(\mathrm{P}<0.05)$ in G3 than G5 (Fig. 1a). In the liver tissue, HSP90, and HSF 1 showed nearly similar expression pattern where they were higher in all groups especially $\mathrm{G} 2$ relative to the control (Fig. 1b).

\section{Discussion}

Managemental factors like SD had a significant effect on bird growth performance, health and welfare. In the present study, high SD in G2 decreased the final BWT compared with birds reared in normal SD. Similarly, Dozier et al. (18) showed that increasing the density produced some negative effects on the live performance of broilers. Addition of VC $(200 \mathrm{mg} / \mathrm{kg}$ diet) to birds reared under high SD ameliorated these negative impacts on growth while failed with the higher levels of VC (600 mg / kg diet). Likewise, Elagib-Hind and Omer (19) reported that BWT was improved by the low and moderate levels (150 and $350 \mathrm{mg} / \mathrm{kg}$ ) of VC compared with the higher level. Also, SabahElkheir et al. (20) observed that VC supplementation at higher doses $(500 \mathrm{mg}$ and $750 \mathrm{mg} / \mathrm{kg}$ ) resulted in lower final weight and weight gain.

Previous studies reported that VC supplementation increased TBG $(21,22)$. On the other hand, others found that broiler feed intake was not affected by the VC supplementation (23, 24). The FCR was improved in all groups reared in high SD with VC supplementation (G3, G4, and G5) compared to G2, and G1. McKee and Harrison (25) also, observed an improvement in FCR of broilers as result of VC supplementation during heat stress. Decreased mortalities with VC supplementation may confirm the relationship between adding $\mathrm{VC}$ and its protective effect as reported by other studies $(26,27)$ which noticed that VC under stress and disease conditions protects the birds by improving the immune response.

Blood serum biochemical parameters are important diagnostic indicators especially under 
stress conditions such as high SD. In the present study, high SD altered the activity of liver function enzymes (SGPT and SGOT), glucose, and, HDL serum concentrations (increased). The increased serum SGPT and SGOT activity in birds reared under high SD indicate that high SD might cause oxidative lesions which are in accordance with the findings of Simsek et al. (28). Dietary inclusion of VC improved these negative impacts of high SD by lowering the levels of the above-mentioned serum parameters. Similarly, Al-Darajji et al. (29) showed that plasma glucose and cholesterol concentration and plasma SGOT and SGPT activities were significantly lowered in both male and female broiler breeder reared under hot climate and supplementation with ascorbic acid. Moreover, Kucuk et al. (30) reported that supplementation with VC decreased MDA, glucose, cholesterol, and triglyceride concentrations in laying hen reared under cold stress.

The significant effect of high stocking density on HSP70 and $\alpha 1$-acid glycoprotein (AGP) indicated that it was physiologically stressful condition to broiler chickens (31). Furthermore, Beloor et al. (32) reported that the expression of HSP70 mRNA could be proper biomarkers to evaluate the stress induced by increased SD. As, HSPs help the stressed cells to manage the stressors, especially those affecting the protein machinery (33). Similarly, the previous study in other species (rainbow trout and sea bass) showed that HSP70 expression level elevated in high SD $(34,35)$. Furthermore, Higher levels of HSP70 gene in different tissues of birds after exposure to environmental stressors is important in the acquisition of stress tolerance (36, 37).

As other study demonstrated that supplementation of VC plays an important role in the prevention of the heat stress in poultry and improvement of their performance (38). Moreover, there is a significant $(\mathrm{P}<0.05)$ difference in HSP70 mRNA expression in heart tissue between $\mathrm{G} 2$ versus $\mathrm{G} 4$ and $\mathrm{G} 5$ which fed on basal diet with 400 and $600 \mathrm{mg} / \mathrm{kg}$ ration VC supplementation. Also, a highly significant difference $(\mathrm{P}<0.0005)$ between $\mathrm{G} 2$ versus $\mathrm{G} 4$ and $\mathrm{G} 5$ and $(\mathrm{P}<0.005)$ between $\mathrm{G} 2$ versus $\mathrm{G} 3$ in the liver tissue were observed (Fig.1b). Similarly, Mahmoud et al. (39) demonstrated that chickens fed a diet supplemented with VC and exposed to cyclic high temperatures showed a significant decreased the expression level of HSP70 compared with control chickens. Furthermore, Jang et al. (40) reported that the mRNA expression of HSP70 in the liver of birds fed a diet containing VC significantly decreased compared with those birds fed basal diet under summer diurnal heat stress. In quail, HSP70 expression in ovary and brain was decreased as the dietary VC or vitamin E supplementation increased in stressed groups (41). Hence, we suggest that VC supplementation act as an antioxidant and helps to prevent the growth of free radicals, which damage cells and subsequently reduced expression of $H S P S$ in chicken reared under high SD.

As the HSFl is a master regulator of the heat shock genes, through activating the HSPs transcription by binding to heat shock element in the upstream promoter region of HSP genes (42). It has the ability to mediate up-regulation of HSP70 and HSP9O which act a critical role in survivability providing to the organisms subjected to stress $(43,44)$. In both heart and liver tissue in the present study, the HSP1 expression showed more increased in G2 whish reared under high SD than G3, G4 and G5 relative to control. Its expression showed the same pattern of HSP70 and HSP90 expression in heart tissue and HSP90 expression in liver tissue. Moreover, Beloor et al. (32) demonstrated that the expression levels of $H S P 90$ in the liver samples were higher in high density group compared with the low and standard groups but, didn't showed significant differences. The current study also showed that stress-induced due to high stocking density increases the expression of HSP70 and HSP90, which play essential protective roles in maintaining the metabolic and structural integrity of the cells and organs against stress-induced injury (45-47).

\section{Conclusions}

Increasing the stocking density from 11.6 to 15.6 birds $/ \mathrm{m}^{2}$ caused stress in broiler chicks 
which tended to reduce their performance, increase mortality rate, affect liver function enzymes (SGPT and SGOT) and change the expression level of heat shock protein genes. Supplementation of VC especially at $200 \mathrm{mg} / \mathrm{kg}$ chick's diet may offer a suitable nutritional strategy to overcome the disadvantageous effects of increased stocking density.

\section{Conflicts of Interest}

The authors declare no conflicts of interest

\section{References}

1. Thaxton JP, Dozier WA, 3rd, Branton SL, Morgan GW, Miles DW, Roush WB, et al.Stocking density and physiological adaptive responses of broilers. Poult Sci 2006; 85(5): 819-24.

2. Pandurang LT, Kulkarni GB, Gangane GR, More PR, Ravikanth K, Maini S, et al.Overcrowding Stress Management in Broiler Chicken with Herbal Antistressor. IJAS 2011; 1(1): 49-55.

3. Whitehead CC, Keller T.An update on ascorbic acid in poultry. World's Poult Sci J 2003; 59(2): 161-84.

4. Zhang AW, Lee BD, Lee SK, Lee KW, An $\mathrm{GH}$, Song KB, et al.Effects of yeast (Saccharomyces cerevisiae) cell components on growth performance, meat quality, and ileal mucosa development of broiler chicks. Poult Sci 2005; 84(7): 1015-21.

5. Campo JL, Dávila S.Changes in heterophil to lymphocyte ratios of heat-stressed chickens in response to dietary supplementation of several related stress agents. Arch Fur Geflugelk 2002; 66: 80-4.

6. Ipek H, Avci M, Yerturk M, Iriadam M, Aydilek N.Effects of ascorbic acid and vitamin $\mathrm{E}$ on performance and hematological parameters of Japanese quails under high ambient temperature in Sanliurfa. Arch Fur Geflugelk 2007; 71: 130-4.

7. Lin H, Jiao HC, Buyse J, Decuypere E.Strategies for preventing heat stress in poultry. World's Poult Sci J 2007; 62(1): 71-86.

8. Al-Aqil A, Zulkifli I.Changes in heat shock protein 70 expression and blood characteristics in transported broiler chickens as affected by housing and early age feed restriction. Poult Sci 2009; 88(7): 1358-64.

9. Zulkifli I, Liew PK, Israf DA, Omar AR, HairBejo M.Effects of early age feed restriction and heat conditioning on heterophil/lymphocyte ratios, heat shock protein 70 expression and body temperature of heat-stressed broiler chickens. J Therm Biol 2003; 28(3): 217-22.
10. Jacquier-Sarlin MR, Fuller K, Dinh-Xuan AT, Richard MJ, Polla BS.Protective effects of hsp70 in inflammation. Experientia 1994; 50(1112): 1031-8.

11. Jackson SE.Hsp90: structure and function. Top Curr Chem 2013; 328: 155-240.

12. NRC, Nutrient requirements of poultry. 9th Ed. Washington, DC:National Academic Press, 1994.

13. Houshmand M, Azhar K, Zulkifli I, Bejo MH, Kamyab A.Effects of prebiotic, protein level, and stocking density on performance, immunity, and stress indicators of broilers. Poult Sci 2012; 91(2): 393-401.

14. Rao X, Huang X, Zhou Z, Lin X.An improvement of the $2^{\wedge}$ (-delta delta CT) method for quantitative real-time polymerase chain reaction data analysis. Biostat, Bioinforma Biomath 2013; 3(3): 71-85.

15. Xie J, Tang L, Lu L, Zhang L, Xi L, Liu HC, et al.Differential expression of heat shock transcription factors and heat shock proteins after acute and chronic heat stress in laying chickens (Gallus gallus). PloS one 2014; 9(7): e102204.

16. Nerren JR, Swaggerty CL, MacKinnon KM, Genovese KJ, He H, Pevzner I, et al.Differential mRNA expression of the avian-specific toll-like receptor 15 between heterophils from Salmonella-susceptible and -resistant chickens. Immunogenetics 2009; 61(1): 71-77.

17. SAS, Statistical Analysis System North Carolina:Users Guide Statistics. As. Institute Cary, 1996.

18. Dozier WA, 3rd, Thaxton JP, Branton SL, Morgan GW, Miles DM, Roush WB, et al.Stocking density effects on growth performance and processing yields of heavy broilers. Poult Sci 2005; 84(8): 1332-8.

19. Elagib-Hind AA, Omer HM.Effect of Dietary Ascorbic Acid on Performance and Immune Response of Heat Stressed Broiler Chicks. Pakistan J Nutr 2012; 11(3): 216-20.

20. SabahElkheir MK, Mohammed AMM, Abdel-Gadir SM.Effect of Feed Restriction and Ascorbic Acid Supplementation on Performance of Broiler Chicks Reared under Heat Stress. Res J Ani \& Vet Sci 2008; 3: 1-8.

21. Sahin K, Kucuk O.Effects of vitamin E and selenium on performance, digestibility of nutrients, and carcass characteristics of Japanese quails reared under heat stress (34 degrees C). J anim Physiol Anim Nutr 2001; 85(11-12): 342-8.

22. Lohakare JD, Ryu MH, Hahn TW, Lee JK, Chae BJ.Effects of Supplemental Ascorbic Acid on 
the Performance and Immunity of Commercial Broilers. J Appl Poult Res 2005; 14(1): 10-19.

23. Blaha J, Kroesna K.Effect of vitamin and electrolytes supplements on broiler performance, slaughter value and chemical composition of meat during the heat stress. Universitäs Agriculturäe Praga Press 1997; 30: 103-13.

24. Jaffar GH, Blaha J.Effect of ascorbic acid supplementation in drinking water on growth rate, feed consumption and feed efficiency of broiler chickens maintained under acute heat stress conditions. Universitas Agriculturae Praga Press 1996; 41: 485-90.

25. McKee JS, Harrison PC.Effects of supplemental ascorbic acid on the performance of broiler chickens exposed to multiple concurrent stressors. Poult Sci 1995; 74(11): 1772-85.

26. Amady V, Tayb I, Yokhana J. Effects of supplemental ascorbic acid on humeral immune response in broilers reared under heat stress conditions. Res Opinions Anim Veter Sci. 2011; 1: 45962.

27. Amakye-Anim J, Lin TL, Hester PY, Thiagarajan D, Watkins BA, Wu CC.Ascorbic acid supplementation improved antibody response to infectious bursal disease vaccination in chickens. Poult Sci 2000; 79(5): 680-8.

28. Simsek UG, Dalkilic B, Ciftci M, Yuce A.The Influences of Different Stocking Densities on Some Welfare Indicators, Lipid Peroxidation (MDA) and Antioxidant Enzyme Activities (GSH, GSH-Px, CAT) in Broiler Chickens. J Anim Vet Adv 2009; 8(8): 1568-72.

29. Al-Darajji H, Al-Mashhadanp E, Al-Atharp A.Effect of ascorbic acid supplementation in the diets on haematological traits of Fawbro broiler breeders reared under hot climate Indian J Anim Sci. 2001; 71(9): 857-9.

30. Kucuk O, Sahin K, Sahin N, Gursu M, Gulcu F, Ozcelik M, et al. Egg production, egg quality, and lipid peroxidation status in laying hens maintained at a low ambient temperature $(6 \mathrm{deg} C)$ and fed a vitamin $\mathrm{C}$ and vitamin E-supplemented diet. Vet Med 2003; 48: 33-40.

31. Najafi P, Zulkifli I, Jajuli NA, Farjam AS, Ramiah SK, Amir AA, et al. Environmental temperature and stocking density effects on acute phase proteins, heat shock protein 70 , circulating corticosterone and performance in broiler chickens. Int $\mathrm{J}$ Biometeorol 2015; 59(11): 1577-83.

32. Beloor J, Kang HK, Kim YJ, Subramani VK, Jang IS, Sohn SH, et al.The Effect of Stocking Density on Stress Related Genes and Telomeric Length in Broiler Chickens. Asian-Aust J Anim Sci 2010; 23(4): 437-43.

33. Basu N, Todgham AE, Ackerman PA, Bibeau MR, Nakano K, Schulte PM, et al.Heat shock protein genes and their functional significance in fish. Gene 2002; 295(2): 173-83.

34. Gornati R, Papis E, Rimoldi S, Terova G, Saroglia M, Bernardini G.Rearing density influences the expression of stress-related genes in sea bass (Dicentrarchus labrax, L.). Gene 2004; 341: 111-8.

35. Aksakal E, Ekinci D, Erdoğan O, Beydemir Ş, Alım Z, Ceyhun SB.Increasing stocking density causes inhibition of metabolic-antioxidant enzymes and elevates mRNA levels of heat shock protein 70 in rainbow trout. Livest Sci 2011; 141(1): 69-75.

36. Craig EA, Gross CA.Is hsp70 the cellular thermometer? Trends in Biochem Sci 1991; 16: 135-40.

37. Parsell DA, Lindquist S.The function of heat-shock proteins in stress tolerance: degradation and reactivation of damaged proteins. Annu Rev Genet 1993; 27: 437-96.

38. Sahin K, Sahin N, Onderci M, Gursu MF, Issi M.Vitamin $\mathrm{C}$ and $\mathrm{E}$ can alleviate negative effects of heat stress in Japanese quails. Food , Agric Envir 2003; 1(2): 244--9.

39. Mahmoud KZ, Edens FW, Eisen EJ, Havenstein GB.Ascorbic acid decreases heat shock protein 70 and plasma corticosterone response in broilers (Gallus gallus domesticus) subjected to cyclic heat stress. Comp Biochem Physiol B Biochem Mol Biol 2004; 137(1): 35-42.

40. Jang IS, Ko YH, Moon YS, Sohn SH.Effects of Vitamin C or E on the Pro-inflammatory Cytokines, Heat Shock Protein 70 and Antioxidant Status in Broiler Chicks under Summer Conditions. Asian-Australas J Anim Sci 2014; 27(5): 749-56.

41. Sahin N, Tuzcu M, Orhan C, Onderci M, Eroksuz Y, Sahin K.The effects of vitamin C and $\mathrm{E}$ supplementation on heat shock protein 70 response of ovary and brain in heat-stressed quail. Br poult sci 2009; 50(2): 259-65.

42. Khassaf M, McArdle A, Esanu C, Vasilaki A, McArdle F, Griffiths RD, et al.Effect of vitamin $\mathrm{C}$ supplements on antioxidant defence and stress proteins in human lymphocytes and skeletal muscle. J Physiol 2003; 549(Pt 2): 645-52.

43. Fangue NA, Hofmeister M, Schulte PM.Intraspecific variation in thermal tolerance and heat shock protein gene expression in common killifish, Fundulus heteroclitus. J Exp Biol 2006; 209(Pt 15): 2859-72.

44. Copat C, Brundo MV, Arena G, Grasso A, Oliveri Conti G, Ledda C, et al.Seasonal variation 
of bioaccumulation in Engraulis encrasicolus (Lin- shock protein 90 in the Antarctic bivalve Laternula neaus, 1758) and related biomarkers of exposure. elliptica. Cell stress chaperones 2009; 14(4): 363Ecotoxicol Environ Saf 2012; 86: 31-7.

45. Yu J, Bao E, Yan J, Lei L.Expression and localization of Hsps in the heart and blood vessel of heat-stressed broilers. Cell stress chaperones 2008; 13(3): 327-35.

46. Kim M, Ahn IY, Kim H, Cheon J, Park 70.

47. Gu XH, Hao Y, Wang XL.Overexpression of heat shock protein 70 and its relationship to intestine under acute heat stress in broilers: 2. Intestinal oxidative stress. Poult Sci 2012; 91(4): 790-9.

H.Molecular characterization and induction of heat 